\title{
PENGARUH PEMBERIAN HORMON AUKSIN DAN GIBERELIN TERHADAP PERTUMBUHAN TOMAT (Solanum lycopersicum L.) Var. AICHI FIRST DI DATARAN MEDIUM
}

\author{
THE EFFECT OF AUXIN AND GIBBERELLIN ON THE GROWTH OF \\ TOMATO (Solanum lycopersicum L.) Var. AICHI FIRST ON MEDIUM PLAIN
}

\author{
Nindi Andianingsih', Arrin Rosmala1, dan Syariful Mubarok ${ }^{2 *}$ \\ 1Program Studi Agroteknologi, Fakultas Pertanian, Universitas Perjuangan Tasikmalaya \\ Jl. PETA No. 177, Kahuripan, Tawang, Kota Tasikmalaya 46115 - Indonesia \\ 2Departemen Budidaya Pertanian, Fakultas Pertanian, Universitas Padjadjaran \\ Jl. Raya Bandung-Sumedang KM. 21, Jatinangor, Sumedang 45363 - Indonesia
}

*Korespondensi: syariful.mubarok@unpad.ac.id

\begin{abstract}
ABSTRAK
Tanaman tomat Aichi First merupakan tanaman sub tropis yang umumnya dibudidayakan di dataran tinggi Indonesia. Kualitas buah tomat yang baik hanya dicapai pada ketinggian $800 \mathrm{mdpl}$. Auksin dan giberelin bekerja sinergis dalam pembentukan bunga dan buah pada tanaman tomat. Pemberian hormon auksin dan giberelin pada tomat kultivar Aichi First diharapkan dapat memacu pertumbuhan, pembungaan dan pembuahan. Penelitian ini bertujuan untuk mengetahui pengaruh pemberian hormon Auksin dan Giberelin dan untuk mendapatkan perlakuan hormon yang paling optimal terhadap pertumbuhan Aichi First di dataran medium. Penelitian dilaksanakan pada bulan Januari-Mei 2020 di kebun percobaan yang terletak di Desa Dadiharja, Kecamatan Rancah, Kabupaten Ciamis. Penelitian menggunakan Rancangan Acak Kelompok (RAK) non faktorial dengan 10 perlakuan dan 3 kali ulangan. Pemberian hormon auksin dan hormon giberelin berpengaruh terhadap tinggi tanaman, akan tetapi tidak berpengaruh pada parameter diameter batang, jumlah tandan, jumlah bunga, umur berbunga, dan luas daun. Konsentrasi auksin 30 ppm + giberelin 80 ppm menghasilkan tinggi tanaman paling tinggi, yaitu sebesar $50.42 \mathrm{~cm}$.
\end{abstract}

Kata kunci: hormone pertumbuhan; auksin; giberelin; dataran medium

\begin{abstract}
Tomato plants are generally cultivated commercially in Indonesia, especially in the highlands. Good quality tomato fruit is only achieved at an altitude of 800 masl. Auxins and gibberellins work synergistically in the formation of flowers and fruit in tomato plants. Giving the hormones auxin and gibberellin to Aichi First cultivar tomatoes is expected to spur growth, flowering and fertilization. This study aims to determine the effect of auxin and gibberellin on the growth of Aichi First and to obtain the optimal hormone treatment. The research was conducted in January-May 2020 in an experimental garden located in Dadiharja Village, Rancah District, Ciamis Regency. The study used a non-factorial randomized block design (RBD) and was repeated 3 times. The administration of auxin hormone and gibberellin hormone affected plant height, but did not affect the parameters of stem diameter, number of bunches, number of flowers, flowering age, and leaf area. The auxin concentration of $30 \mathrm{ppm}+$ gibberellin $80 \mathrm{ppm}$ produced the highest plant height, which was $50.42 \mathrm{~cm}$.
\end{abstract}

Keywords: growth hormone; auxin; gibberellin; medium plains 


\section{PENDAHULUAN}

Tomat merupakan salah satu sayuran yang umum dikonsumsi di dunia. Buah tomat dimanfaatkan di antaranya sebagai sumber vitamin dan mineral. Kandungan zat gizi pada $100 \mathrm{~g}$ buah tomat adalah vitamin C $40 \mathrm{mg}$, vitamin A (karoten) 1500 SI, vitamin B (tiamin) 60 ug, karbohidrat (4,2 g), lemak $(0,3 \mathrm{~g})$, protein $(1 \mathrm{~g})$, zat besi $(0,5$ $\mathrm{mg}$ ), kalsium (5 $\mathrm{mg}$ ), fosfor (27 $\mathrm{mg}$ ) (Handrian et al., 2013).

Menurut Badan Pusat Statistik (2016), produksi tomat di Indonesia pada tahun 2011 sebesar 954.046 ton, tahun 2012 mengalami penurunan produksi menjadi 893.504 ton, pada tahun 2013 mengalami peningkatan produksi dari tahun sebelumnya mencapai 992.780 ton, pada tahun 2014 dan 2015 produksi tomat kembali menurun yaitu 916.001 ton dan 877.801 ton. Berdasarkan data ekspor dan impor tahun 2011 (Direktorat Jenderal Hortikultura (2013) Indonesia mengimpor tomat dalam bentuk sayuran segar sebesar 18 ton, tomat dalam bentuk sayuran olahan sebesar 8.651 ton. Data tersebut menunjukkan bahwa Indonesia kebutuhan konsumsi tomat dalam negeri masih tergantung pada impor, terutama tomat untuk bahan industri dan dalam bentuk sudah menjadi barang olahan.
Tanaman tomat dapat tumbuh baik di dataran tinggi maupun dataran rendah tergantung varietasnya. Suatu varietas tomat perlu diketahui karakteristik pertumbuhannya pada suatu lokasi (Pongoh, 2011). Menurut Purwati dan Khirunnisa (2012), daerah penyebaran tomat di Indonesia cukup luas, mulai dari ketinggian 19-700 mdpl, dimana tomat yang dibudidayakan di daerah tropis cenderung lebih produktif di dataran tinggi daripada di dataran rendah. Akan tetapi, pengembangan budidaya tomat di dataran tinggi terbatas pada lahan yang tersedia, serta budidaya tanaman tomat berpotensi menimbulkan erosi. Sehingga perluasan untuk budidaya tomat diarahkan ke dataran rendah

Tomat yang menghadapi Kepala putik cepat kering dan tabung sari, terjadi kerusakan pollen dan sel telur, menghambat pembentukan dan pertumbuhan buah, sehingga tidak banyak terjadi pembentukan buah pada suhu udara yang terlalu panas (Syukur, 2011).

Auksin berperan memacu proses pemanjangan sel. Fungsi lain dari auksin adalah merangsang kambium untuk membentuk xylem dan floem. Giberelin merupakan hormon yang berfungsi sinergis dengan hormon auksin. Giberelin berpengaruh terhadap perkembangan dan perkecambahan embrio. 
Pemberian hormon giberelin dalam berbagai konsentrasi menunjukkan adanya perbedaan bobot buah dan bobot biji buah tomat varitas tombatu F1. Konsentrasi terbaik hormon giberelin adalah 100 ppm yang ditunjukkan dengan bobot buah sebesar $8107 \pm 159 \mathrm{~g}$ dan bobot biji sebesar $0.05 \pm 0.010$ g (Permatasari et al., 2016). Menurut Zaini et al. (2017) konsentrasi auksin yang tepat untuk meningkatkan pertumbuhan tanaman adalah 1-3 ml dalam $1 \mathrm{~L}$ air. Jika konsentrasi IAA terlalu tinggi menyebabkan pemanjangan sel batang menjadi terhambat. Penelitian mengenai aplikasi auksin dan giberelin terhadap pertumbuhan dan hasil tomat Aichi First belum banyak dilakukan. Oleh karena itu, perlu dilakukan penelitian mengenai pengaruh hormon yang optimal untuk pertumbuhan tanaman tomat var Aichi First.

Berdasarkan latar belakang di atas maka tujuan penelitian ini yaitu Untuk mengetahui pengaruh pemberian hormon auksin dan giberelin terhadap pertumbuhan tomat Aichi First. Untuk mendapatkan perlakuan hormon auksin dan giberelin yang paling optimal terhadap pertumbuhan tomat Aichi First.

\section{METODE PENELITIAN}

Penelitian dilaksanakan pada Januari sampai Mei 2020 di kebun percobaan yang terletak di Desa Dadiharja, Kecamatan Rancah, Kabupaten Ciamis, dan ketinggian tempat 491.915 mdpl dengan ketepatan $3.2 \mathrm{~m}$, lintang $-7.1505705^{\circ} \mathrm{LU}$ dengan garis bujur $108.5002405^{\circ} \mathrm{BT}$.

Alat yang digunakan dalam penelitian ini adalah meteran, penggaris, timbangan, kamera digital, ajir, tali rafia, spayer, cangkul, papan nama, polybag, gelas ukur, soil tester, $\mathrm{pH}$ meter, soil thermometer, gunting, dan mulsa plastik hitam perak. Bahan yang digunakan adalah tomat Aichi First, giberelin, auksin, larutan fungisida, larutan insektisida, dan pupuk kandang.

Penelitian ini menggunakan Rancangan Acak Kelompok (RAK). Perlakuan :

$A=\operatorname{Kontrol}(0 \mathrm{ppm})$

$\mathrm{B}=\mathrm{IAA}(25 \mathrm{ppm})$

$\mathrm{C}=\mathrm{IAA}(50 \mathrm{ppm})$

$\mathrm{D}=$ Giberelin $(80 \mathrm{ppm})$

$\mathrm{E}=$ Giberelin $(100 \mathrm{ppm})$

$\mathrm{F}=\mathrm{IAA}(25 \mathrm{ppm})+$ Giberelin $(80 \mathrm{ppm})$

$\mathrm{G}=\mathrm{IAA}(25 \mathrm{ppm})+$ Giberelin (100 ppm)

$\mathrm{H}=\mathrm{IAA}(50 \mathrm{ppm})+$ Giberelin $(80 \mathrm{ppm})$

$\mathrm{I}=\mathrm{IAA}(50 \mathrm{ppm})+$ Giberelin $(100 \mathrm{ppm})$

Setiap perlakuan diulang 3 kali, sehingga didapat 27 petak percobaan. Setiap perlakuan ditanam 6 tanaman dalam 2 baris. Panjang dan lebar bedengan $6 \mathrm{~m} \times 1,2 \mathrm{~m}$, dengan jarak tanam $60 \mathrm{~cm} \times 60 \mathrm{~cm}$. 


\section{Variabel Pengamatan}

\section{Pengamatan Penunjang:}

Curah hujan harian rata-rata yang terletak di Kabupaten Ciamis dan Ciamis Kota, temperatur udara harian dan kelembapan udara relatif. Jenis hama dan penyakit yang menyerang tanaman tomat Aichi First.

\section{Pengamatan Utama:}

Tinggi tanaman $(\mathrm{cm})$, luas daun $\left(\mathrm{cm}^{2}\right)$, diameter batang $(\mathrm{cm})$, jumlah tandan, umur berbunga (hari), dan jumlah bunga per tandan.

\section{Pelaksanaan Penelitian}

Persemaian

Dengan merendam biji dalam larutan fungisida selama 1 jam kemudian dikeringkan setelah itu biji disemai pada tray semai berisi media tanam $100 \mathrm{~g}$ dengan perbandingan tanah dan pupuk kandang 2:1.

\section{Penanaman}

Bibit tanaman tomat yang ditanam berumur 3 minggu dan memiliki dua daun lebih. Penanaman dilakukan pada pagi hari.

\section{Pemberian hormon}

\begin{tabular}{lllr}
\multicolumn{3}{c}{ Aplikasi } & \multicolumn{2}{r}{ hormon giberelin } \\
dilakukan saat & umur & bunga & mekar \\
berumur 3 & hari, & dengan & cara \\
disemprotkan & ke & seluruh & bagian \\
tanaman, dilakukan 1 & minggu & sekali. \\
Auksin diaplikasikan dengan & cara \\
mencelup bibit kelarutan hormon.
\end{tabular}

Hormon auksin dapat disemprotkan ke bagian bawah daun, disiram ataupun dikocorkan ke akar.

\section{Pemeliharaan}

Pemeliharaan tanaman meliputi penyulaman, pemasangan ajir, penyiangan, pemangkasan, pengikatan tanaman, penyiraman, pemupukan, dan pengendalian hama penyakit tanaman tomat.

\section{Analisis Data}

Data yang diperoleh diolah menggunakan sidik ragam (Uji F) pada taraf nyata 5\% dengan menggunakan program aplikasi STAR (Statistical Tool for Agricultural Reseach). Apabila hasil uji berbeda nyata, dilanjutkan dengan uji Tukey.

\section{HASIL DAN PEMBAHASAN}

\section{Tinggi Tanaman}

Hasil analisis ragam tinggi tanaman pada 6 MST disajikan pada Tabel 1. Hasil pengamatan menunjukan bahwa pengaruh perlakuan hormon terhadap tinggi tanaman berpengaruh nyata pada pengamatan 6 MST. Berdasarkan data rata-rata tinggi tanaman, perlakuan $\mathrm{H}$ memberikan tinggi tanaman tertinggi yaitu sebesar $50.42 \mathrm{~cm}$, sedangkan perlakuan D memberikan tinggi tanaman tomat terendah yaitu sebesar $43.17 \mathrm{~cm}$. 
Tabel 1. Nilai rerata tinggi tanaman tomat pada 6 MST

\begin{tabular}{lc}
\hline \multicolumn{1}{c}{ Perlakuan } & Tinggi Tanaman (cm) \\
\hline A (Kontrol) & $43.17 \mathrm{~b}$ \\
B (Auksin 25 ppm) & $43.33 \mathrm{~b}$ \\
C (Auksin 50 ppm) & $46.42 \mathrm{ab}$ \\
D (Giberelin 80 ppm) & $45.92 \mathrm{ab}$ \\
E (Giberelin 100 ppm) & $48.42 \mathrm{ab}$ \\
F (Auksin 25 ppm + Giberelin 80 ppm) & $48.33 \mathrm{ab}$ \\
G (Auksin 25 ppm + Giberelin 100 ppm) & $46.58 \mathrm{ab}$ \\
H (Auksin 50 ppm + Giberelin 80 ppm) & $50.42 \mathrm{a}$ \\
I (Auksin 50 ppm + Giberelin 100 ppm) & $48.17 \mathrm{ab}$ \\
\hline Keterangan: Nilai rata-rata yang ditandai huruf yang sama pada kolom yang sama menunjukan tidak berbeda
\end{tabular}
nyata menurut Tukey pada taraf $5 \%$.

Perlakuan H (Auksin 50 ppm + Giberelin $80 \mathrm{ppm}$ ) memberikan tinggi tanaman paling tinggi, karena kandungan auksin dan giberelin yang cukup besar. Pemberian hormon giberelin secara eksogen memacu pertumbuhan batang dan daun muda, sehingga proses fotosintesis lebih terpacu dan menghasilkan peningkatan pertumbuhan pada seluruh organ tanaman, termasuk akar (Sundhari et al., 2014). Menurut penelitian Dinda et al. (2016), induksi giberelin berpengaruh nyata terhadap parameter panjang tanaman tomat. Hal ini seiring dengan penelitian yang dilakukan oleh Maharani et al. (2018), bahwa tinggi tanaman Kailan bertambah akibat pemberian $\mathrm{GA}_{3} 20$ ppm. Sedangkan konsentrasi 40 ppm tidak memberikan penambahan tinggi tanaman Kailan.

Pemberian NAA $30 \mathrm{ppm}$ dapat meningkatkan tinggi tanaman dan jumlah anak daun pada tomat varietas Juliet F1. Sedangkan aplikasi 150 ppm dapat menurunkan diameter buah tomat Puspitasari et al. (2014). Auksin mampu merangsang pertumbuhan tunas-tunas baru karena auksin yang terdapat pada pucuk-pucuk tunas muda dan pada jaringan meristem di pucuk, hormon ini berfungsi sebagai pengatur pembesaran pada sel dan memicu perpanjangan dari sel pada daerah belakang meristem ujung serta membantu proses pertumbuhan batang (Hasibuan, 2014).

Penelitian yang dilakukan Gurjar et al. (2018) menyatakan bahwa terdapat peningkatan tinggi tanaman dan jumlah cabang tanaman tomat pada konsentrasi 20 ppm NAA dan 5 ppm $\mathrm{GA}_{3}$. Akan tetapi terdapat penurunan tinggi tanaman dan jumlah cabang yang diberi perlakuan 40 ppm NAA dan 10 ppm GA3. Hormon NAA dan $\mathrm{GA}_{3}$ dapat memacu pertumbuhan tetapi pada konsentrasi yang tinggi dapat menurunkan pertumbuhan. 
Diameter Batang dan Jumlah Tandan Bunga

Hasil analisis ragam pada Tabel 2 berpengaruh nyata terhadap diameter batang dan jumlah tandan tanaman tomat.

menunjukan perlakuan tidak

Tabel 2. Nilai rerata diameter batang dan jumlah tandan bunga pada 6 MST

\begin{tabular}{lcc}
\hline \multicolumn{1}{c}{ Perlakuan } & $\begin{array}{c}\text { Diameter Batang } \\
\text { (mm) }\end{array}$ & $\begin{array}{c}\text { Jumlah Tandan } \\
\text { Bunga (buah) }\end{array}$ \\
\hline A (Kontrol) & 5.12 & 6.00 \\
B (Auksin 25 ppm) & 4.57 & 5.58 \\
C (Auksin 50 ppm) & 4.81 & 5.83 \\
D (Giberelin 80 ppm) & 4.8 & 6.33 \\
E (Giberelin 100 ppm) & 5.06 & 5.67 \\
F (Auksin 25 ppm + Giberelin 80 ppm) & 4.42 & 5.67 \\
G (Auksin 25 ppm + Giberelin 100 ppm) & 4.38 & 6.08 \\
H (Auksin 50 ppm + Giberelin 80 ppm) & 4.45 & 6.4 \\
I (Auksin 50 ppm + Giberelin 100 ppm) & 4.34 & 7.08 \\
\hline Keterangan: Nilai rata-rata yang ditandai huruf yang sama pada kolom yang sama menunjukan tidak berbeda
\end{tabular}

Berdasarkan data, perlakuan A (Kontrol) menghasilkan diameter $5.12 \mathrm{~mm}$, lebih besar daripada perlakuan lain. Sedangkan perlakuan I (Auksin 50 ppm + Gibrelin 100 ppm) memberikan nilai jumlah tandan 7.08 buah, lebih banyak dibandingkan perlakuan lain. Perlakuan hormon dan kombinasinya, tidak memberikan pengaruh terhadap pertumbuhan diameter dan jumlah tandan tanaman tomat. Hal ini sejalan dengan penelitian Apriliani et al. (2015) pada stek pucuk bayur, dimana pemberian konsentrasi dan jenis auksin yang berbeda tidak memberikan pengaruh. Hal ini dikarenakan kandungan auksin endogen pada tanaman sudah cukup, dan menyebabkan pemberian auksin eksogen tidak akan memberikan mempercepat pertumbuhan tanaman.

\section{Umur Berbunga dan Jumlah Bunga per Tandan}

Analisis ragam parameter umur berbunga dan jumlah bunga per tanda disajikan pada Tabel 3. Hasil analisis menunjukkan perlakuan tidak memberikan pengaruh yang tidak berbeda nyata.

Berdasarkan Tabel 3, perlakuan B (60 ppm) dan perlakuan D (Giberelin 80 ppm) cenderung memberikan umur berbunga yang lebih cepat dibandingkan dengan perlakuan lainnya (hari ke-60). Sedangkan perlakuan G (Auksin 25 ppm + Giberelin $100 \mathrm{ppm}$ ) cenderung memberikan jumlah bunga lebih banyak (11 buah) dibandingkan dengan perlakuan lain. 
Kuncup bunga muncul tidak serempak dikarenakan pemberian perlakuan konsentrasi yang berbeda pada tiap tanaman tomat. Sundahri et al.
(2014) menyatakan bahwa hormon giberelin berpengaruh pada inisiasi bunga dan bekerja pada gen membutuhkan konsentrasi yang tepat

Tabel 3. Nilai rerata umur berbunga dan jumlah bunga per tandan tanaman tomat pada 8 MST

\begin{tabular}{lcc}
\hline \multicolumn{1}{c}{ Perlakuan } & Umur Berbunga (hari) & $\begin{array}{c}\text { Jumlah Bunga Per } \\
\text { Tandan (buah) }\end{array}$ \\
\hline A (Kontrol) & 60.17 & 7.50 \\
B (Auksin 25 ppm) & 60.00 & 6.25 \\
C (Auksin 50 ppm) & 60.25 & 5.50 \\
D (Giberelin 80 ppm) & 60.00 & 6.75 \\
E (Giberelin 100 ppm) & 60.50 & 9.00 \\
F (Auksin 25 ppm + Giberelin 80 ppm) & 60.17 & 8.50 \\
G (Auksin 25 ppm + Giberelin 100 ppm) & 60.47 & 11.0 \\
H (Auksin 50 ppm + Giberelin 80 ppm) & 60.18 & 10.0 \\
I (Auksin 50 ppm + Giberelin 100 ppm) & 60.28 & 9.50 \\
\hline
\end{tabular}

Keterangan: Nilai rata-rata yang ditandai huruf yang sama pada kolom yang sama menunjukan tidak berbeda nyata menurut Tukey pada taraf $5 \%$.

Inisiasi dari pertumbuhan dan fruit set tanaman tomat sangat dipengaruhi oleh lingkungan. Pembentukan fruit set tomat dipengaruhi oleh kondisi lingkungan seperti temperatur tinggi ataupun temperatur yang rendah, karena dapat menghambat pembentukan polen dan menyebabkan pecahnya serbuk sari. Hal ini menyebabkan gagalnya pembuahan, sehingga tidak terbentuk buah (Jong et al., 2019). Tomat Aichi first adalah jenis tomat beef yang berasal dari derah subtropika. Tingginya suhu di Ciamis menyebabkan bunga tomat Aichi First rontok sehingga tidak terjadi pembuahan.

$$
\text { Husnul dan Ana }
$$
menyatakan bahwa giberelin berperan dalam inisiasi bunga, giberelin berperan mempercepat pembungaan tanaman melalui pengaktifan gen meristem bunga dengan menghasilkan protein yang akan menginduksi ekspresi gen-gen pembentukan organ bunga. Giberelin sebagai salah satu hormon tumbuh pada tanaman, mempunyai peranan dalam pembungaan. Umumnya giberelin tinggi menyebabkan tanaman terhambat berbunga, sebaliknya tanaman terinduksi berbunga apabila kandungan giberelinnya menurun.

Muhyidin et al. (2018) mengatakan pembentukan bunga dari kuncup hingga mekar dipengaruhi oleh faktor lingkungan. Air hujan atau penyiraman yang berlebihan dapat menyebabkan kuncup bunga membusuk sebelum mekar.

\section{Luas Daun}

Berdasarkan hasil analis ragam terhadap luas daun pada 7 MST yang diuraikan pada Tabel 4, menujukan hasil 
tidak berbeda nyata antar perlakuan. Luas daun sampel bagian atas menunjukan perlakuan $\mathrm{F}$ (Auksin 25 ppm + Giberelin 80 ppm) dengan nilai $9.27 \mathrm{~cm}^{2}$ memberikan hasil luas daun lebih luas daripada perlakuan lain. Perlakuan E (Giberelin 100 ppm) memberikan luas daun pada sampel bagian tengah lebih tinggi dari pada perlakuan lain $\left(20.55 \mathrm{~cm}^{2}\right)$. Perlakuan $\mathrm{F}$ (Auksin 25 ppm + Giberelin 80 ppm) pada daun sampel bagian bawah memberikan nilai rata-rata $8.66 \mathrm{~cm}^{2}$, lebih tinggi daripada perlakuan lain.

Tabel 4. Nilai rerata luas daun tanaman tomat umur 7 MST

\begin{tabular}{lccc}
\hline \multicolumn{1}{c}{ Perlakuan } & $\begin{array}{c}\text { Bawah } \\
\left(\mathbf{c m}^{\mathbf{2}}\right)\end{array}$ & $\begin{array}{c}\text { Tengah } \\
\left(\mathbf{c m}^{\mathbf{}} \mathbf{)}\right.\end{array}$ & $\begin{array}{c}\text { Atas } \\
\left(\mathbf{c m}^{\mathbf{}} \mathbf{)}\right.\end{array}$ \\
\hline A (Kontrol) & 7.66 & 19.10 & 7.66 \\
B (Auksin 25 ppm) & 8.09 & 19.80 & 9.22 \\
C (Auksin 50 ppm) & 7.94 & 19.60 & 8.55 \\
D (Giberelin 80 ppm) & 8.22 & 20.00 & 8.44 \\
E (Giberelin 100 ppm) & 8.55 & 20.55 & 9.00 \\
F (Auksin 25 ppm + Giberelin 80 ppm) & 8.66 & 20.05 & 9.27 \\
G (Auksin 25 ppm + Giberelin 100 ppm) & 8.16 & 20.50 & 8.94 \\
H (Auksin 50 ppm + Giberelin 80 ppm) & 8.50 & 20.11 & 8.16 \\
I (Auksin 50 ppm + Giberelin 100 ppm) & 8.27 & 20.11 & 8.83 \\
\hline
\end{tabular}

Keterangan: Nilai rata-rata yang ditandai huruf yang sama pada kolom yang sama menunjukan tidak berbeda nyata menurut Tukey pada taraf $5 \%$.

\begin{abstract}
Perlakuan hormon tidak memberikan hasil yang nyata pada parameter pertumbuhan dikarenakan kandungan hormon endogennya sudah mencukupi. Sehingga pemberian hormon eksogen tidak akan memberikan pengaruh yang nyata (Apriliani et al., 2015).
\end{abstract}

\section{KESIMPULAN}

Berdasarkan hasil dan pembahasan diatas, maka dapat ditarik kesimpulan bahwa pemberian hormon auksin dan giberelin berpengaruh terhadap tinggi tanaman. Akan tetapi tidak berpengaruh terhadap diameter batang, jumlah tandan, jumlah bunga, umur berbunga, dan luas daun. Konsentrasi auksin $50 \mathrm{ppm}+$ giberelin 80 ppm mampu menghasilkan tanaman tertinggi yaitu sebesar $50.42 \mathrm{~cm}$.

\section{DAFTAR PUSTAKA}

Apriliani, A., Noli, Z.A., \& Suwirmen. (2015). Pemberian beberapa jenis dan konsentrasi auksin untuk menginduksi perakaran pada stek pucuk buyur (Pterospermun javanicum Jungh) dalam upaya perbanyakan tanaman revegetasi. $J$ Biologi Universitas Andalas 4(3), 178187.

Badan Pusat Statistik (BPS) RI [Internet]. (2016). Produksi sayuran di indonesia.

https://www.bps.go.id/site/resultTa b. Diakses pada Tanggal 03 September 2020. 
Dinda, A., Permatasari., Yuni S.R., \& Evie, R. (2016). Pengaruh pemberian hormon giberelin terhadap pertumbuhan buah secara partenokarpi pada tanaman tomat varitas tombatu F1. J Lentera Bio 5 (1), 25-31.

Direktorat Jenderal Hortikultura. (2013). Data ekspor impor komoditi tomat. https://www.hortikultura.pertanian. go.id.

Gurjar, J.S., Banafar, R.S., Gupta, N.K., Gurjar, P.K.S., \& Singh, L. (2018). Effect of NAA, $\mathrm{GA}_{3}$ on growth and yeld of tomato varieties. $J$ of Pharmacognosy and Phytochemistry 7(5), 3157-3160.

Handrian, R.G., Meiriani., \& Haryati. (2013). Peningkatan kadar vitamin C buah tomat (Lycopersicum esculentum MILL.) dataran rendah dengan pemberian hormon $\mathrm{GA}_{3}$. Jurnal Online Agroekoteknologi 2(1), 333-339.

Hasibuan, S.P., \& Malayu. (2014). Manajemen sumber daya manusia. Jakarta (ID): Bumi Aksara.

Husnul., \& Ana, H. (2013). Pengaruh hormon giberelin dan auksin terhadap umur pembungaan dan persentase bunga menjadi buah pada tanaman tomat. J Hort 11 (1), 66-72.

Jong, M.C., Mariani, W.H., \& Vriezen. (2019). The role of auxin and gibberellin in tomato fruit set. $J$ of Experimental Botani 6(5), 15231532.

Maharani, A., Sawirmen., \& Noli, Z.A. (2018). Pengaruh Konsentrasi Giberelin $\left(\mathrm{GA}_{3}\right)$ terhadap pertumbuhan Kailan (Brassica deraceae L. Var aboglabra) pada berbagai media tanam dengan hidroponik Eick System. J Biologi Universitas Andalas 6(2), 63-70.
Muhyidin, H., Islami, T., \& Maghfoer, M.D. (2018). Pengaruh konsentrasi dan waktu pemberian giberelin pada pertumbuhan dan hasil tanaman tomat (Lycopersicum esculentum Mill.). J. Produksi Tanaman 6(6), 1147-1154.

Pongoh, J. (2011). Penampilan beberapa varietas tomat pada dua kondisi lingkungan. J Eugenia 17(2), 142150.

Permatasari., Dinda, A., Yuni., Sri, R., \& Ratnasari, E. (2016). Pengaruh pemberian hormon giberelin terhadap pertumbuhan buah secara partenokarpi pada tanaman tomat varietas Tombatu F1. J LenteraBio 5(1), 25-37.

Purwati, E., \& Khirunnisa. (2012). Budidaya tomat dataran rendah. Jakarta (ID): Penebar Swadaya.

Puspitasari, Y.D., Aini, N., \& Koesriharti. (2014). Respon dua varietas tomat (Lycopersicum esculentum Mill.) terhadap aplikasi zat pengatur tumbuh Napthalene Acetic Acid (NAA). J Produksi Tanaman 2(7), 566-575.

Sundhari, Hariyanti, N., \& Setiyono, T. (2014). Efektivitas pemberian giberelin terhadap pertumbuhan dan produksi tomat. J Agritop Ilmuilmu Pertanian 14(1), 42-47.

Syukur, A. (2011). Analisis iklim mikro di dalam rumah tanaman untuk memprediksi waktu permbungaan dan matang fisiologis tanaman tomat dengan menggunakan metode artificial neutral network. $J$ Agroland 18(2), 97-103.

Zaini, M., Adnan., \& Juanda, B.R. (2017). Pengaruh konsentrasi dan lama perendaman dalam ZPT auksin terhadap viabilitas benih semangka (Citurullus lunatus). J. Penelitian 4(1), 45-55. 